\title{
Metal concentrations in river water and bed sediments of the Lower Litani River Bassin, Lebanon
}

Nada Nehme, Chaden Haydar, Bachar Koubaissy, Mohamad Fakih, Sadek Awad, Joumana Toufaily, Frederic Villieras, Tayssir Hamieh,

MCEMA Laboratory, Faculty of Sciences I, EDST, Lebanese University, Beirut, Lebanon. And Faculty of Agriculture, Lebanese University, Beirut, Lebanon

nadanehme530@hotmail.com

MCEMA Laboratory, Faculty of Sciences I, EDST, Lebanese University, Beirut, Lebanon. And Faculty of Agriculture, Lebanese University, Beirut, Lebanon chadenyaacoub@hotmail.com

MCEMA Laboratory, Faculty of Sciences I, EDST, Lebanese University, Beirut, Lebanon. And Faculty of Agriculture, Lebanese University, Beirut, Lebanon bachar.kobaissy@ul.edu.lb

MCEMA Laboratory, Faculty of Sciences I, EDST, Lebanese University, Beirut, Lebanon. And Faculty of Agriculture, Lebanese University, Beirut, Lebanon fakih.mohamad@gmail.com

MCEMA Laboratory, Faculty of Sciences I, EDST, Lebanese University, Beirut, Lebanon. And Faculty of

Agriculture, Lebanese University, Beirut, Lebanon sadekawad@yahoo.fr

MCEMA Laboratory, Faculty of Sciences I, EDST, Lebanese University and School of Mechanical and Materials Engineering, WSU, Pullman, WA 99164, USA .joumana.toufaily@ul.edu.lb

Laboratoires Environnement et Minéralurgie, LEM, Nancy, France, UMR756 frederic.villieras@univ-lorraine.fr

MCEMA Laboratory, Faculty of Sciences I, EDST, Lebanese University, Beirut, Lebanon. And Faculty of Agriculture, Lebanese University, Beirut, Lebanon tayssir.hamieh@ul.edu.lb

\section{ABSTRACT}

The distribution of pollutants in the Litani River is almost severe. It resulted from domestic, sewage, agricultural and industrial sources. In this study, the distribution of metals ( $\mathrm{Cu}, \mathrm{Fe}, \mathrm{Cd}, \mathrm{Mg}, \mathrm{Zn}, \mathrm{Pb}, \mathrm{Al}, \mathrm{Ba}, \mathrm{Ni}, \mathrm{Mn}, \mathrm{Ag}$ and $\mathrm{Cr}$ ) were measured in river water and the bed sediments of the Lower Litani River Basin (LLRB). The impacts of metals on the water quality were monitored during the rainy, mid rainy and dry season in the year 2012. The objectives of this study were first to identify possible sources of metals (i.e. geological and/or anthropogenic) and then to characterize the chemical behavior of these metals in water and bed sediments. Water and bed load sediments were sampled at six sites along the LLRB main watercourse, The metal concentrations in the river sediments were remarkably high, but varied between different sampling sites, and the concentrations in water were mainly within the permissible limits. The metal contents in bed sediment were highest during closure of summer period. By applying the principal component analysis applied to total and extractable metal contents as a tool for studying metal pollution in the LLRB, it was useful to distinguish between anthropogenic and natural sources.

\section{Keywords}

Litani River; water; sediment; zinc; contamination; seasonal variations.

\section{Academic Discipline And Sub-Disciplines}

Physical chemistry, sediment, river water, pollution;

\section{TYPE (METHOD/APPROACH)}

\section{Council for Innovative Research}

Peer Review Research Publishing System

Journal: Journal of Advances in Chemistry

Vol. 8, No. 2

editor@cirjac.com 


\section{INTRODUCTION}

Most environmental regulations have established limitations for the total heavy metal concentration in water, thus they must not exceed some quality criteria for the protection of the environment and human life Sediments act as a major source of heavy metals [1] and also as a source of Contaminants. Thus, the determination of the extent of pollution by a given heavy metal requires that the pollutant metal concentration must be compared with an unpolluted reference material. Lebanese rivers are subjected to pollution from many sources [2] and development of an effective water usage strategy requires effective pollution remediation and, in turn, better information on the geochemical properties of the rivers and their capacities for self Purification.

The Litani River drains nearly one fifth of the waters of Lebanon and has a $2170 \mathrm{~km}^{2}$ watershed that extends between latitudes $33^{0} 50^{\prime} \mathrm{N}$ and longitudes $35^{\circ} 15^{\prime} \mathrm{E}$. Geomorphologically, the Litani River Basin is divided into two sub-basins (Figure 1), with the upper one stretching from the Bekaa plain to the Qaraoun dam and the lower part extended from the Qaraoun dam to reach the coast [3].

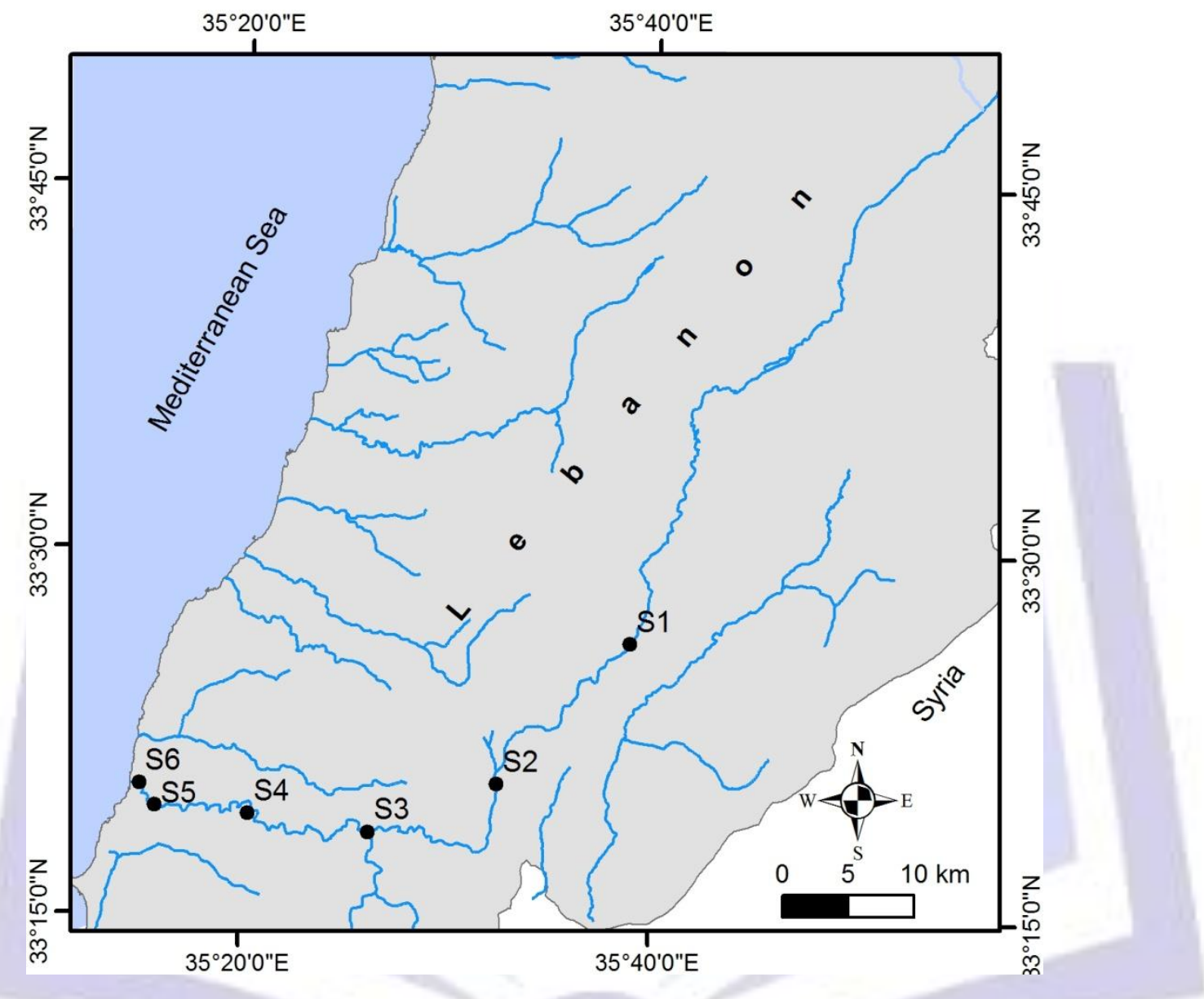

Fig. 1: The study area of the Lower Litani River Basin(LLRB).

The LLRB consists of one primary river course and eight secondary branches; It encompasses eight districts or administrative Caza hosting a population of about 133,000 persons [4]. Previous research in our laboratory showed that The major sources of pollutants are local anthropogenic activities, agricultural runoff due to a high level of $\mathrm{NO}_{2}^{-}, \mathrm{Fe}^{-}$and $\mathrm{CaCO}_{3}[5]$.

For much of the year pollutants enter the fluvial system will be incorporated into bed sediments by precipitation and sorption over the surface layer of static bed sediments.

Sediments are a habitat and major nutrient source for aquatic organisms. Sediment analysis is

important in evaluating qualities of total ecosystem of a body of water, in addition to water sample analysis practiced for many years because it reflects the long term quality situation independent of the current inputs [6].

Heavy metals are among the most common environmental pollutants, and their occurrence in water and sediments indicates the presence of natural or anthropogenic sources. The main natural sources of metals in waters are chemical weathering of minerals in rocks and soil leaching. The anthropogenic sources are associated mainly with industrial and domestic effluents, urban storm, water runoff, landfill, atmospheric sources and inputs rural areas [7-9].

The aim of the current study is to clarify the spatial and temporal variations in heavy metal concentrations including Copper (Cu), Iron (Fe), Cadmium (Cd), zinc ( $\mathrm{Zn})$, Plomb (Pb),Magnesium (Mg) ,Aluminum (Al), Barium (Ba), Nickel (Ni), Manganese $(\mathrm{Mn})$, Silver $(\mathrm{Ag})$, Chrome $(\mathrm{Cr})$, in surface water and bed sediment in LLRB in Lebanon. Furthermore, the role of 
pollution sources in the LLRBL on the water quality was assessed as well as the relationships between metal concentrations was analyzed.

\section{MATERIALS AND METHODS}

\section{The study area}

For water and bed sediments sampling, six sampling sites were selected along the LLRB (Table 1) describe the major activities. This was done during the rainy, mid rainy, dry seasons of 2012.

Table 1. Location and description of the study sites in LLRB

\begin{tabular}{|l|l|l|l|l|}
\hline Sampling site & Symboles & Latitude & Longitude & Major activities \\
\hline Qelia & $\mathrm{S} 1$ & $\begin{array}{l}33^{\circ} 26^{\prime} 21^{\prime \prime} \\
\mathrm{N}\end{array}$ & $35^{\circ} 38^{\prime \prime} 55^{\prime} \mathrm{E}$ & Quarry site and Touristic zones pumping stations. \\
\hline Kardali & $\mathrm{S} 2$ & $\begin{array}{l}33^{\circ} 20^{\prime} \\
34^{\prime} \mathrm{N}\end{array}$ & $33^{\circ} 32^{\prime} 34^{\prime \prime} \mathrm{E}$ & Agriculture and touristic zone. \\
\hline $\begin{array}{l}\text { Kaekaeyat } \\
\text { eljisr }\end{array}$ & $\mathrm{S} 3$ & $\begin{array}{l}33^{\circ} 18^{\prime} \\
31^{\prime} \mathrm{N}^{\prime}\end{array}$ & $35^{\circ} 26^{\prime} 18^{\prime \prime} \mathrm{E}$ & Touristic and agriculture zone small village \\
\hline Tair flsaiy & $\mathrm{S} 4$ & $33^{\circ} 19^{\prime} 1 \mathrm{O}^{\prime} \mathrm{N}$ & $35^{\circ} 20^{\prime} 27^{\prime} \mathrm{E}$ & Touristic zone. \\
\hline Abou abdellah & $\mathrm{S} 5$ & $\begin{array}{l}33^{\circ} 19^{\prime} 26^{\prime \prime} \\
\mathrm{N}\end{array}$ & $35^{\circ} 15^{\prime} 50^{\prime \prime} \mathrm{E}$ & Vegetated sites with citrus tree \\
\hline Qasmieh & $\mathrm{S} 6$ & $\begin{array}{l}33^{\circ} 20^{\prime} \\
22^{\prime \prime} \mathrm{N}\end{array}$ & $35^{\circ} 15^{\prime} 04^{\prime \prime} \mathrm{E}$ & $\begin{array}{l}\text { Road with high traffic density, irrigation canal and } \\
\text { agricultural zone with banana. }\end{array}$ \\
\hline
\end{tabular}

These sites were selected because they receive considerable amounts of waste water from the surrounding industrial areas, as well as from intensively cultivated agricultural areas and domestic wastes from towns and villages.

\section{Water and bed sediment sampling, chemical and statistical analysis}

Six water and bed sediment samples were collected once in three times before, during rainy, mid rainy, dry periods from February to September 2012. For the water, six water samples were collected in a 1-I polyethylene bottles soaked overnight with $10 \%(\mathrm{v} / \mathrm{v})$ nitric acid was used for water sampling collection. The samples were filtered by filtration system through membrane filter of pore size $0.45 \mu \mathrm{m}$ before analyses using Standard Methods [10].

The method of sampling and collection are in accordance with Standard Methods APHA, AWWA, WPCF [10]. The samples were transported to the laboratory in portable coolers. Thus, $\mathrm{pH}$, electrical Conductivity and Total Dissolve Solid were estimated directly at the sampling sites. While the other nutrients parameters were measured in the laboratory. Samples were analyzed for water quality indicators including: $\mathrm{pH}$, total dissolved solids (TDS), conductivity (EC),

The concentrations of ( $\mathrm{Cu}, \mathrm{Fe}, \mathrm{Cd}, \mathrm{Mg}, \mathrm{Zn}, \mathrm{Pb}, \mathrm{Al}, \mathrm{Ba}, \mathrm{Ni}, \mathrm{Mn}, \mathrm{Ag}$ and $\mathrm{Cr}$ ) were measured using the Atomic Absorption Spectrophotometric method, (Spectrophotometer (RAYLEICH -MFX-210) with an air/acetylene flame and background correction and a deuterium lamp to remove solid impurities before testing (AOAC 974.27).

Bed sediment samples were digested using microwave digestion techniques as reported by [11] in which $0.25 \mathrm{gm}$ of each sample was placed in Teflon vessel with $5 \mathrm{~mL} \mathrm{HNO} 65 \%), 2 \mathrm{~mL} \mathrm{HF} \mathrm{(40 \% )} \mathrm{and} 2 \mathrm{~mL} \mathrm{H}_{2} \mathrm{O}_{2} \quad(30 \%)$ by using Microwave digestion system (model: MILESTONE mls- 200 mega).

(An aliquot of the filtration of the samples was taken (about $100 \mathrm{ml}$ ). Digestion solutions were measured for total heavy metals using ICP-OES [12].

Correlation coefficients were calculated between all pairs of the measured element concentrations. Multivariate statistical analyses such as Pearson correlation analysis, Factor analysis (FA) were performed to reflect the degree of dispersion distribution of different metals Pearson's correlation analysis was carried out by using SPSS16 2007.

\section{RESULTS AND DISCUSSION}

\section{Metals in water}

The means of element concentrations in the water samples are presented in Table 2. The results showed that, most of the heavy metal concentrations are in surface water of LLRB. The mean values of the elements at different sites showed that $\mathrm{Fe}$ is the most abundant element in all points followed by $\mathrm{Pb}, \mathrm{Cd}, \mathrm{Cr}, \mathrm{Ag}$, and $\mathrm{Ni}$. The concentrations of $\mathrm{Ba}, \mathrm{Ni}, \mathrm{Al}, \mathrm{Zn}, \mathrm{Mg}, \mathrm{Cu}$ are within the norms (Table 2). 
Table 2. The element concentrations measured from the water samples (mg/L).

\begin{tabular}{|c|c|c|c|c|c|c|c|c|c|}
\hline $\begin{array}{l}\text { Heavy } \\
\text { metal }\end{array}$ & Period & S1 & S2 & S3 & S4 & S5 & S6 & $\begin{array}{l}\text { WHO } \\
(2006)\end{array}$ & $\begin{array}{l}\text { Libnor } \\
\text { (1999) }\end{array}$ \\
\hline \multirow{4}{*}{$\mathrm{Cu}$} & RS & 0.02 & 0.2 & 0.2 & 0.2 & 0.2 & 0.2 & & \\
\hline & MRS & 0.03 & 0.05 & 0.1 & 0.05 & 0.02 & 0.2 & & \\
\hline & DS & 0.05 & 0.05 & 0.05 & 0.05 & 0.05 & 0.05 & & \\
\hline & Mean & 0.03 & 0.10 & 0.12 & 0.10 & 0.09 & 0.15 & $1 \mathrm{mg} / \mathrm{L}$ & $1 \mathrm{mg} / \mathrm{L}$ \\
\hline \multirow{4}{*}{$\mathrm{Fe}$} & RS & 1 & 6 & 3 & 2 & 7 & 6 & & \\
\hline & MRS & 1 & 11 & 1 & 1 & 2 & 2 & & \\
\hline & DS & 0.02 & 0.08 & 0.09 & 0.04 & 0.04 & 0.08 & & \\
\hline & Mean & 0.67 & 5.69 & 1.36 & 1.01 & 3.01 & 2.69 & $0.3 \mathrm{mg} / \mathrm{L}$ & $0.3 \mathrm{mg} / \mathrm{L}$ \\
\hline \multirow{4}{*}{ Cd } & $\mathrm{RS}$ & 0 & 0.1 & 0.1 & 0.1 & 0.1 & 0.1 & & \\
\hline & MRS & 0.01 & 0 & 0 & 0.01 & 0.02 & 0.02 & & \\
\hline & DS & 0.01 & 0.02 & 0.02 & 0.02 & 0.02 & 0.02 & & \\
\hline & Mean & 0.01 & 0.04 & 0.04 & 0.04 & 0.05 & 0.05 & $0.005 \mathrm{mg} / \mathrm{L}$ & $0.005 \mathrm{mg} / \mathrm{L}$ \\
\hline \multirow[t]{4}{*}{ Mg } & $\mathrm{RS}$ & 1 & 1 & 1 & 1 & 1 & 1 & & \\
\hline & MRS & 1 & 1 & 1 & 1 & 1 & 1 & & \\
\hline & DS & 2.02 & 2.87 & 1.62 & 3.26 & 11.37 & 12.19 & & \\
\hline & Mean & 1.34 & 1.62 & 1.21 & 1.75 & 4.46 & 4.73 & $50 \mathrm{mg} / \mathrm{L}$ & $50 \mathrm{mg} / \mathrm{L}$ \\
\hline \multirow{4}{*}{ Zn } & $\mathrm{RS}$ & 0.5 & 0.3 & 0.2 & 0.2 & 0.2 & 0.2 & & \\
\hline & MRS & 0.5 & 0.3 & 0.3 & 0.2 & 0.2 & 0.2 & & \\
\hline & DS & 0 & 0.02 & 0.03 & 0.03 & 0.02 & 0 & & \\
\hline & Mean & 0.33 & 0.21 & 0.18 & 0.14 & 0.14 & 0.13 & $5 \mathrm{mg} / \mathrm{L}$ & $5 \mathrm{mg} / \mathrm{L}$ \\
\hline \multirow{4}{*}{$\mathrm{Pb}$} & RS & 0.1 & 0.07 & 0.09 & 0.1 & 0.07 & 0.1 & & \\
\hline & MRS & 0.1 & 0.07 & 0.09 & 0.1 & 0.07 & 0.1 & & \\
\hline & DS & 0.01 & 0.07 & 0.06 & 0.05 & 0.21 & 0.05 & & \\
\hline & Mean & 0.07 & 0.07 & 0.08 & 0.08 & 0.12 & 0.08 & $0.01 \mathrm{mg} / \mathrm{L}$ & $0.01 \mathrm{mg} / \mathrm{L}$ \\
\hline \multirow{4}{*}{ Al } & RS & 0.02 & 0.03 & 0.04 & 0.05 & 0.05 & 0.05 & & \\
\hline & MRS & 0.02 & 0.03 & 0.04 & 0.05 & 0.05 & 0.05 & & \\
\hline & DS & 0.05 & 0.08 & 0.07 & 0.05 & 0.01 & 0.01 & & \\
\hline & Mean & 0.03 & 0.05 & 0.05 & 0.05 & 0.04 & 0.04 & $0.2 \mathrm{mg} / \mathrm{L}$ & $0.2 \mathrm{mg} / \mathrm{L}$ \\
\hline \multirow[t]{4}{*}{$\mathrm{Ba}$} & $\mathrm{RS}$ & 0.05 & 0.05 & 0.03 & 0.03 & 0.02 & 0.08 & & \\
\hline & MRS & 0.05 & 0.05 & 0.03 & 0.03 & 0.02 & 0.08 & & \\
\hline & DS & 0.06 & 0.03 & 0.03 & 0.04 & 0.08 & 0.12 & & \\
\hline & Mean & 0.05 & 0.04 & 0.03 & 0.03 & 0.04 & 0.09 & $0.5 \mathrm{mg} / \mathrm{L}$ & $0.5 \mathrm{mg} / \mathrm{L}$ \\
\hline \multirow{4}{*}{$\mathrm{Ni}$} & RS & 0.02 & 0.02 & 0.01 & 0.01 & 0.01 & 0.01 & & \\
\hline & MRS & 0.02 & 0.02 & 0.01 & 0.01 & 0.01 & 0.01 & & \\
\hline & DS & 0 & 0.01 & 0.02 & 0.01 & 0.01 & 0.01 & & \\
\hline & Mean & 0.01 & 0.02 & 0.01 & 0.01 & 0.01 & 0.01 & $0.02 \mathrm{mg} / \mathrm{L}$ & $0.02 \mathrm{mg} / \mathrm{L}$ \\
\hline \multirow{5}{*}{ Mn } & RS & 0 & 0 & 0.01 & 0 & 0 & 0.01 & & \\
\hline & MRS & 0 & 0 & 0.01 & 0 & 0 & 0.01 & 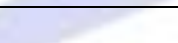 & \\
\hline & DS & 0 & 0.01 & 0.01 & 0 & 0.01 & 0.01 & & \\
\hline & Mean & 0.00 & 0.00 & 0.01 & 0.00 & 0.00 & 0.01 & $0.05 \mathrm{mg} / \mathrm{L}$ & $0.05 \mathrm{mg} / \mathrm{L}$ \\
\hline & RS & 0.02 & 0.02 & 0.02 & 0.02 & 0.02 & 0.02 & & \\
\hline \multirow[t]{3}{*}{$\mathrm{Ag}$} & MRS & 0.02 & 0.02 & 0.02 & 0.02 & 0.02 & 0.02 & & \\
\hline & DS & 0.02 & 0.02 & 0.02 & 0.02 & 0.02 & 0.02 & & \\
\hline & Mean & 0.02 & 0.02 & 0.02 & 0.02 & 0.02 & 0.02 & $0.01 \mathrm{mg} / \mathrm{L}$ & $0.01 \mathrm{mg} / \mathrm{L}$ \\
\hline \multirow{4}{*}{$\mathrm{Cr}$} & RS & 0.1 & 0.1 & 0.1 & 0.1 & 0.1 & 0.1 & & \\
\hline & MRS & 0.3 & 0.1 & 0.15 & 0.02 & 0 & 0.01 & & \\
\hline & DS & 0 & 0.01 & 0.01 & 0.01 & 0.01 & 0.01 & & \\
\hline & Mean & 0.13 & 0.07 & 0.09 & 0.04 & 0.04 & 0.04 & $0.05 \mathrm{mg} / \mathrm{L}$ & $0.05 \mathrm{mg} / \mathrm{L}$ \\
\hline PH & Mean & 8.1 & 8.2 & 8.4 & 8.5 & 8.4 & 7.8 & $6.5-8.5$ & $6.5-8.5$ \\
\hline TDS & Mean & 299 & 233.6 & 279.75 & 272.5 & 335 & 300.7 & $500 \mathrm{mg} / \mathrm{L}$ & $500 \mathrm{mg} / \mathrm{L}$ \\
\hline Ec & Mean & 587.5 & 446.1 & 473.7 & 475.5 & 627.5 & 561.2 & $1500 \mu \mathrm{s} / \mathrm{cm}$ & $1500 \mu \mathrm{s} / \mathrm{cm}$ \\
\hline
\end{tabular}

(RS): Rainy season; (MRS): Mid rainy season; (DS) Dry season.

Metals such as $\mathrm{Ba}, \mathrm{Ni}, \mathrm{Al}, \mathrm{Zn}, \mathrm{Mg}, \mathrm{Cu}$ were found within the permissible limits according to WHO [13] and Libnor. It was found that agricultural and industrial activities are mainly responsible for high levels of the measured elements in river water. The Fe concentrations were highest at the sites of (S2) and (S5) because of the presence of cultivated land and wastes water..

Generally, given heavy metals concentrations were higher during summer closure period, which is due to lower 
discharging rates of water and the elements adsorb and precipitate on the sediment particles resulting from low $\mathrm{pH}$ values and microbial activity [14].

Table 3 shows that the concentrations of $\mathrm{Mg}$ and $\mathrm{Zn}$ during the rainy season were higher than those after the dry period, because of the increased consumption of this element by the phytoplankton [15].

Much correlation occurs during this study, Cd was significantly positively correlated with $\mathrm{Cu}(r=0.85)$ and $\mathrm{Fe}(r=0.45)$ (Table 3) and this is due to the same source origin of contamination. The major sources of these elements in fresh water include atmospheric deposition, manufacturing processes related to chemicals and metals, is the discharges of municipal waste and domestic wastes and atmospheric deposition.

Table 3. Correlation coefficient matrix for metals of water during the period of 2012

\begin{tabular}{|c|c|c|c|c|c|c|c|c|c|c|c|c|}
\hline & $\mathrm{Cu}$ & $\mathrm{Fe}$ & $\mathrm{Cd}$ & $\mathrm{Mg}$ & $\mathrm{Zn}$ & $\mathrm{Pb}$ & $\mathrm{Al}$ & $\mathrm{Ba}$ & $\mathrm{Ni}$ & $\mathrm{Mn}$ & $\mathrm{Ag}$ & $\mathrm{Cr}$ \\
\hline $\mathrm{Cu}$ & 1.00 & & & & & & & & & & & \\
\hline $\mathrm{Fe}$ & 0.29 & 1.00 & & & & & & & & & & \\
\hline $\mathrm{Cd}$ & $\mathbf{0 . 8 5}$ & 0.45 & 1.00 & & & & & & & & & \\
\hline $\mathrm{Mg}$ & 0.46 & 0.22 & $\mathbf{0 . 6 4}$ & 1.00 & & & & & & & & \\
\hline $\mathrm{Zn}$ & -0.83 & -0.20 & -0.95 & $-\mathbf{0 . 5 9}$ & 1.00 & & & & & & & \\
\hline $\mathrm{Pb}$ & 0.09 & -0.05 & 0.54 & $\mathbf{0 . 6 5}$ & -0.51 & 1.00 & & & & & & \\
\hline $\mathrm{Al}$ & $\mathbf{0 . 5 8}$ & 0.34 & 0.55 & -0.27 & -0.57 & -0.09 & 1.00 & & & & & \\
\hline $\mathrm{Ba}$ & 0.37 & 0.10 & 0.16 & $\mathbf{0 . 6 5}$ & -0.11 & -0.11 & -0.47 & 1.00 & & & & \\
\hline $\mathrm{Ni}$ & 0.02 & $\mathbf{0 . 8 7}$ & 0.66 & -0.27 & 0.14 & -0.35 & 0.40 & -0.15 & 1.00 & & & \\
\hline $\mathrm{Mn}$ & $\mathbf{0 . 6 4}$ & -0.34 & 0.39 & 0.23 & -0.59 & -0.18 & 0.30 & 0.36 & -0.40 & 1.00 & & \\
\hline $\mathrm{Ag}$ & 0.00 & 0.00 & 0.00 & 0.00 & 0.00 & 0.00 & 0.00 & 0.00 & 0.00 & 0.00 & 0.00 & \\
\hline $\mathrm{Cr}$ & -0.69 & -0.32 & $\mathbf{0 . 9 0}$ & -0.67 & $\mathbf{0 . 9 4}$ & -0.52 & -0.45 & -0.18 & 0.02 & -0.54 & 0.00 & 1.00 \\
\hline
\end{tabular}

The correlation was positively between Fe and $\mathrm{Zn}(0.34)$; $\mathrm{Mg}$ and $\mathrm{Mn}(r=0.40)$; Ba and $\mathrm{Mn}(r=0.39)$. The negative correlation between $\mathrm{Mg}$ and $\mathrm{Zn}$ concentrations because they are not from the same sources of pollution $(r=-0.53)$ is may be a result of precipitation of the elements as hydrous metal oxides [16].

\section{Principal component analysis}

Despite that the pollution at some sites being explained, multivariate analysis must be applied so as to unambiguously describe the pollution sources for each metal. By applying of the multivariate technique of principal components analysis to the matrix of 12 features (total concentration of $\mathrm{Cd}, \mathrm{Cr}, \mathrm{Ni}, \mathrm{Pb}$ and $\mathrm{Cu} .$. ) and 6 samples of the LLRB, four components were extracted describing approximately $97.53 \%$ of the common variance (Table 4).

Table 4. Factor loadings of elements data in the water samples

\begin{tabular}{|c|c|c|c|c|}
\hline Variables & F1 & F2 & F3 & F4 \\
\hline $\mathrm{Cu}$ & -0.87 & 0.11 & 0.24 & $\mathbf{0 . 2 8}$ \\
\hline $\mathrm{Fe}$ & -0.33 & $\mathbf{0 . 7 2}$ & -0.56 & 0.24 \\
\hline $\mathrm{Cd}$ & -0.97 & 0.15 & -0.08 & -0.11 \\
\hline $\mathrm{Mg}$ & -0.70 & -0.46 & -0.53 & $\mathbf{0 . 1 0}$ \\
\hline $\mathrm{Zn}$ & $\mathbf{0 . 9 7}$ & -0.01 & -0.15 & 0.17 \\
\hline $\mathrm{Pb}$ & -0.47 & -0.29 & -0.48 & -0.68 \\
\hline $\mathrm{Al}$ & -0.48 & $\mathbf{0 . 7 0}$ & 0.49 & -0.18 \\
\hline $\mathrm{Ba}$ & -0.30 & -0.48 & -0.28 & $\mathbf{0 . 7 8}$ \\
\hline $\mathrm{Ni}$ & 0.06 & $\mathbf{0 . 9 0}$ & -0.29 & 0.29 \\
\hline $\mathrm{Mn}$ & -0.56 & -0.32 & $\mathbf{0 . 6 6}$ & 0.31 \\
\hline $\mathrm{Ag}$ & 0.00 & 0.00 & 0.00 & 0.00 \\
\hline $\mathrm{Cr}$ & $\mathbf{0 . 9 4}$ & -0.02 & 0.03 & 0.11 \\
\hline Eigenvalues & $\mathbf{5 . 0 0}$ & $\mathbf{2 . 4 8}$ & $\mathbf{1 . 7 5}$ & $\mathbf{1 . 4 7}$ \\
\hline \%Variance & $\mathbf{4 5 . 5 4}$ & $\mathbf{2 2 . 5 9}$ & $\mathbf{1 5 . 9 6}$ & $\mathbf{1 3 . 4 4}$ \\
\hline \% cumulative & $\mathbf{4 5 . 5 4}$ & $\mathbf{6 8 . 1 2}$ & $\mathbf{8 4 . 0 8}$ & $\mathbf{9 7 . 5 3}$ \\
\hline
\end{tabular}

Table 4. shows that $\mathrm{F} 1$ describe $45.54 \%$ of the common variance and is highly loaded by $\mathrm{Zn}, \mathrm{Cr}$, Ni and is the negatively correlated with $\mathrm{Mn}$ and $\mathrm{Mg}$. F2 describes $22.59 \%$ of the common variance and is highly loaded by the elements $\mathrm{Fe}, \mathrm{Al}$, $\mathrm{Cu}$ and $\mathrm{Cd}$. F2 is negatively correlated with $\mathrm{Pb}, \mathrm{Mn}, \mathrm{Ag}$ and $\mathrm{Ba}$. The third factor $\mathrm{F} 3$ describes $15.98 \%$ of the common 
variances of data and positively correlated with Mn, F4 describes $13.44 \%$ of the common variances of data and positively correlated with $\mathrm{Ba}, \mathrm{Mn}, \mathrm{Fe}, \mathrm{Mg}$ and $\mathrm{Cu}$.

The results in the Figure 2 show that the classification by seasons is not important and this appear in the Figure 2, for examples the class $1 \backslash 3$ contains S2 RS, S2 MR, S1 RS and S3 MRS and not all the selected sites of winter selection. This class $1 \backslash 3$ was found in positive side of the axis of $\mathrm{F} 11$ and have the same character.

The class $3 \backslash 3$ opposite to $F 1$ and F2 was found in the negative site and the class $1 \backslash 3$ and class $2 \backslash 3$ are in the positive site of $\mathrm{F} 1$ and $\mathrm{F} 2$, the effect of parameters varies by seasons due to the variation in temperature as well as the rainfall periods and the different source of pollution.

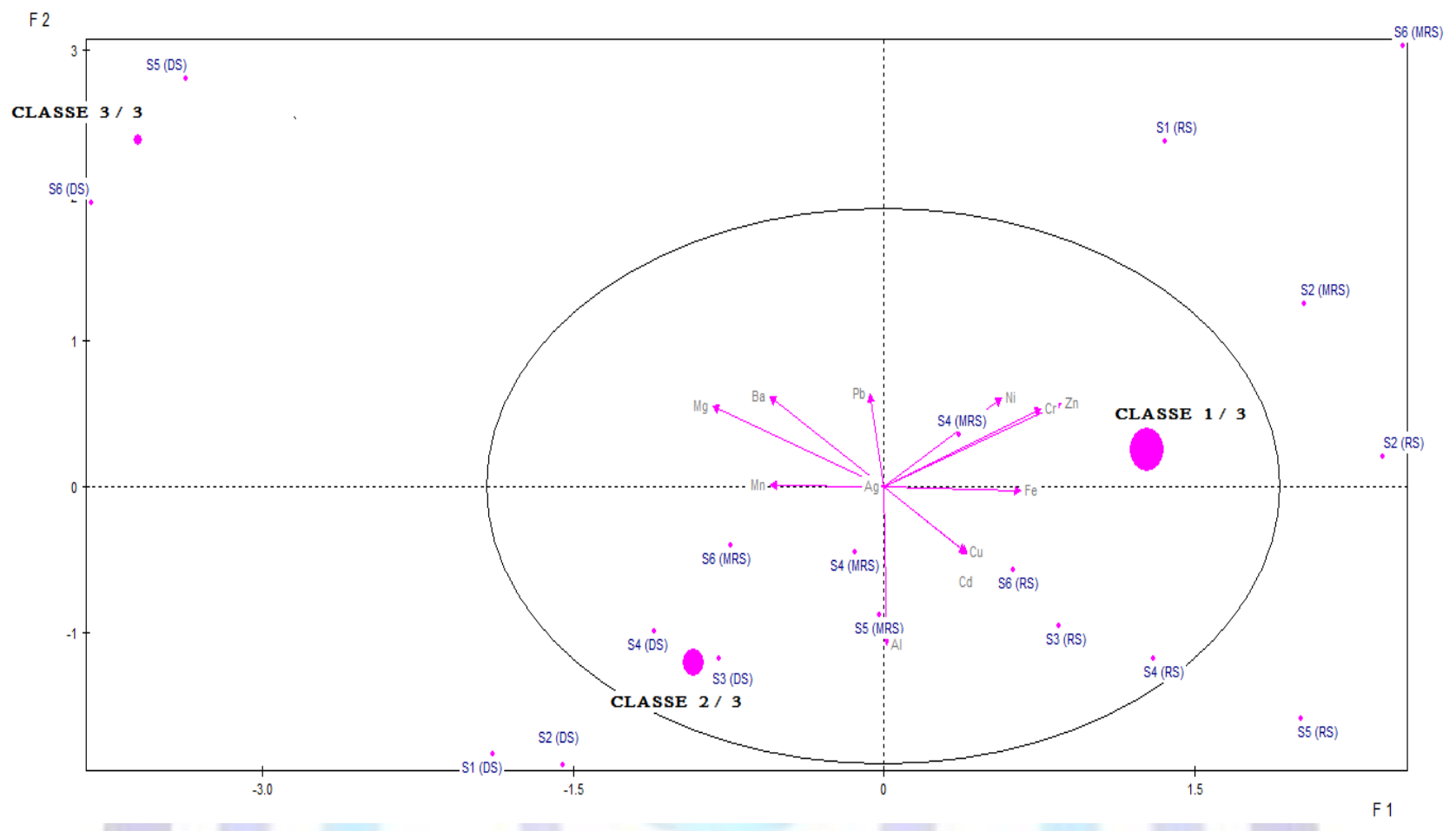

Fig. 2: Factorial F1, F2 classification by season.

Figure 2 shows that the distribution in the first class is characterize by the presence of $\mathrm{Zn}, \mathrm{Cr}$, and Ni is characterized by the presence of many industries and the reject of waste water without recycling $(\mathrm{Cr})$,

In the third class were found in the positive site of F2 and negative site of the axis of F1 and which are characterize by the presence of $\mathrm{Pb}, \mathrm{Mn}, \mathrm{Mg}$ and Bawhich are the main natural characteristics of the water in the site S4,S5,S6.

Site $\mathrm{S} 1$ is characterized by the presence of $\mathrm{Zn}$ and $\mathrm{Cr}$, than the site S2 and S3 has the main source of pollution Ni in the opposite site $\mathrm{S} 4, \mathrm{~S} 5$ and $\mathrm{S} 6$ is characterize by the presence of $\mathrm{Pb}, \mathrm{Mn}, \mathrm{Mg}$ and $\mathrm{Ba}$.

$\mathrm{Fe}, \mathrm{Cu}^{-}, \mathrm{Cd}$ and $\mathrm{Al}$, is present in the S6, S3 and S4, this is normal in the sites because all around villages reject their waste without any treatment.

\section{HEAVY METALS IN SEDIMENTS}

Sediment analysis plays an important role in assessing the pollution status of the environment [17] the analysis of heavy metals levels in sediment samples helps in the interpretation of water quality [18].

Many heavy metals concentrations in sediment; especially in the fine grained sediments which act as a transport agent in the water column, are at least three orders of magnitude higher than the same metals in surrounding water [8].

Resulted data from sediments can provide information on the impact of distant human activity on the wider ecosystem. The composition of sediment sequences provides the best natural archives of recent environmental changes.

Determination and speciation of heavy metals pollution is one of a primary target in environmental research [19, 20].

Therefore, the analysis of heavy metals in sediments enables the detection of pollution deteriorating water quality and provides information about the "critical sites" of the water system [21, 22].

Variations in the contents of studied elements in the river bed sediment were observed to be as following: Cu:0-44 mg kg1, Fe: $980-26000 \mathrm{mg} \mathrm{kg}^{-1}$, Cd: 2-18 mg, Mg: 600-5366 mg kg ${ }^{-1}, \mathrm{Zn}: 2-224 \mathrm{mg} \mathrm{kg}^{-1}$, pb:0-106 mg kg ${ }^{-1}, \mathrm{Al}^{-1} 3200-35962 \mathrm{~m} \mathrm{~g}$

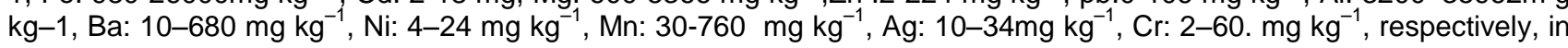
each time period (Table 5). 
Table 5. The element contents in bed sediment samples along LLRB ( $\mathrm{mg} \mathrm{kg}^{-1}$, dry weight). RS: Rainy season, MRS: midrainy season, DS: dry season: After winter period, ISQGs: Interim freshwater sediment quality guidelines, No guideline available: *):

\begin{tabular}{|c|c|c|c|c|c|c|c|c|c|}
\hline Heavy metal & Period & $\mathbf{S 1}$ & S2 & S3 & S4 & S5 & S6 & CBSQG, Mg Kg & ISQG, $\mathrm{Mg} \mathrm{Kg}^{-1}$ \\
\hline \multirow{4}{*}{$\mathrm{Cu}$} & RS & 10 & 40 & 20 & 40 & 0 & 0 & & \\
\hline & MRS & 14 & 42 & 100 & 30 & 134 & 60 & & \\
\hline & DR & 14 & 0 & 0 & 0 & 0 & 14 & & \\
\hline & Mean & 12 & 28 & 40 & 24 & 44 & 24 & 32 & 35.7 \\
\hline \multirow[b]{4}{*}{$\mathrm{Fe}$} & $\mathrm{RS}$ & 980 & 1636 & 1200 & 7000 & 12000 & 4800 & & \\
\hline & MRS & 980 & 14000 & 20000 & 10000 & 20000 & 26000 & & \\
\hline & DS & 980 & 15118 & 22398 & 10920 & 20040 & 30954 & & \\
\hline & Mean & 980 & 10252 & 14532 & 9306 & 17346 & 20584 & * & 20000 \\
\hline \multirow[b]{4}{*}{ Cd } & RS & 2 & 10 & 10 & 10 & 10 & 10 & & \\
\hline & MRS & 2 & 6 & 4 & 10 & 6 & 8 & & \\
\hline & DS & 2 & 14 & 32 & 22 & 34 & 36 & & \\
\hline & Mean & 2 & 10 & 16 & 14 & 16 & 18 & 0.99 & 0.6 \\
\hline \multirow[b]{4}{*}{ Mg } & $\mathrm{RS}$ & 1000 & 1000 & 600 & 800 & 4000 & 1800 & & \\
\hline & MRS & 600 & 800 & 800 & 800 & 4000 & 4600 & & \\
\hline & DR & 600 & 776 & 1068 & 666 & 4566 & 5366 & 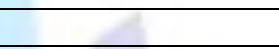 & \\
\hline & Mean & 734 & 858 & 822 & 756 & 4188 & 3922 & * & * \\
\hline \multirow[b]{4}{*}{$\mathrm{Zn}$} & RS & 80 & 224 & 200 & 60 & 60 & 40 & & \\
\hline & MRS & 80 & 10 & 10 & 6 & 20 & 6 & & \\
\hline & DS & 80 & 54 & 2 & 26 & 12 & 68 & & \\
\hline & Mean & 80 & 96 & 70 & 30 & 30 & 38 & 120 & 123 \\
\hline \multirow{4}{*}{$\mathrm{Pb}$} & $\mathrm{RS}$ & 14 & 88 & 100 & 20 & 100 & 100 & & \\
\hline & MRS & 14 & 0 & 20 & 0 & 20 & 80 & & \\
\hline & $\mathrm{DR}$ & 14 & 0 & 22 & 0 & 40 & 136 & & \\
\hline & Mean & 14 & 30 & 48 & 6 & 54 & 106 & 35 & 35 \\
\hline \multirow[b]{4}{*}{ Al } & RS & 4000 & 3600 & 4000 & 3200 & 6000 & 28000 & & \\
\hline & MRS & 8000 & 3400 & 10000 & 4800 & 15400 & 20000 & - & \\
\hline & DR & 8000 & 3536 & 10976 & 5528 & 15418 & 35962 & & \\
\hline & Mean & 6666 & 3512 & 8326 & 4510 & 12272 & 27988 & * & * \\
\hline \multirow[b]{4}{*}{$\mathrm{Ba}$} & $\mathrm{RS}$ & 20 & 230 & 60 & 100 & 40 & 40 & 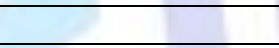 & \\
\hline & MRS & 32 & 10 & 24 & 10 & 98 & 680 & & \\
\hline & DR & 32 & 28 & 38 & 14 & 98 & 670 & 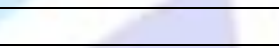 & \\
\hline & Mean & 28 & 90 & 40 & 24 & 78 & 464 & 500 & 750 \\
\hline \multirow[b]{4}{*}{$\mathrm{Ni}$} & $\mathrm{RS}$ & 4 & 4 & 4 & 4 & 4 & 4 & & \\
\hline & MRS & 4 & 4 & 4 & 10 & 6 & 24 & & \\
\hline & DR & 4 & 4 & 4 & 10 & 6 & 24 & & \\
\hline & Mean & 4 & 4 & 4 & 8 & 6 & 18 & 23 & * \\
\hline \multirow[b]{4}{*}{ Mn } & $\mathrm{RS}$ & 432 & 760 & 400 & 200 & 400 & 600 & & \\
\hline & MRS & 200 & 324.16 & 294.06 & 698.44 & 486.34 & 464.1 & & \\
\hline & DR & 432 & 30 & 180 & 38 & 272 & 452 & & \\
\hline & Mean & 354 & 372 & 292 & 312 & 386 & 506 & 460 & * \\
\hline \multirow{4}{*}{$\mathrm{Ag}$} & RS & 10 & 26 & 10 & 10 & 10 & 10 & & \\
\hline & MRS & 10 & 10 & 10 & 20 & 10 & 10 & & \\
\hline & DR & 14 & 34 & 14 & 20 & 14 & 14 & & \\
\hline & Mean & 12 & 24 & 12 & 16 & 12 & 12 & * & * \\
\hline \multirow[b]{4}{*}{$\mathrm{Cr}$} & $\mathrm{RS}$ & 2 & 10 & 10 & 10 & 20 & 40 & & \\
\hline & MRS & 36 & 8 & 38 & 46 & 44 & 60 & & \\
\hline & DR & 2 & 10 & 10 & 28 & 20 & 60 & & \\
\hline & Mean & 14 & 10 & 20 & 28 & 28 & 54 & 43 & 37.3 \\
\hline
\end{tabular}

(RS): Rainy season; (MRS): Mid rainy season; (DS) Dry season

The mean concentrations of the heavy metals in sediment in rainy, mid-rainy and dry season were higher than the values recommended in Consensus-Based Sediment Quality Guidelines of Wisconsin (CBSQG) [23] and ISQGs: Interim freshwater sediments quality guidelines as shown in Table 5. 
The mean concentrations of $\mathrm{Cd}, \mathrm{Mg}, \mathrm{Al}, \mathrm{Ba}, \mathrm{Ni}$ and $\mathrm{Ag}$ were higher in the dry season than in the wet season probably due to the dilution by rainwater which influences concentration and heavy metal mobility.

However, it has been reported that mobility of heavy metals depends not only on the total concentration in the soil and sediments but also on the soil or sediment properties themselves, metal properties and environmental factors.

According to the Table 5, the concentration of iron in Site 1 was not varied during the 3 sampling, but we showed that the effect of season is important because the concentration of Fe increase during the dry season, and thus conduct to conclude that the presence of Fe in sediments is geologically derived.

The high concentrations of Fe that was found in the sediments may be mainly resulted from the natural deposits and industry, where $\mathrm{Fe}$ is one of the chemicals used for drilling operations.

$\mathrm{Cd}$ may be explained by the fact that $\mathrm{Cd}$ in sediments is associated with the carbonate fraction and concentrates on the suspended matter in water [24].

Domestic and industrial effluents are the major sources of the observed high level of $\mathrm{Pb}, \mathrm{Zn}, \mathrm{Co}, \mathrm{Cu}$, and $\mathrm{Cr}$ are mainly precipitated as soluble oxide [25].

It was concluded that water $\mathrm{pH}$ (7.8-8.5) was typical for a river located on a karstic rock exposures, that Fe in the sediments was derived from geological sources, whereas $\mathrm{Cu}, \mathrm{Pb}$ and $\mathrm{Zn}$ were anthropogenic in their origin.

The high concentrations of the studied elements may be attributed to the effect of intrusion of water borne $\mathrm{Fe}, \mathrm{Mg}, \mathrm{Cu}, \mathrm{Zn}$, $\mathrm{Pb}$ and $\mathrm{Cd}$ derived from agricultural, domestic and industrial effluents, and the small grain size of the sediment facilitates the adsorption of these metals to bed sediments.

Table 6 shows that there are many metals positively correlated together and this explained by their capacity of retention by the sediment. Positive correlation coefficients are observed among the metals $\mathrm{Cu}, \mathrm{Fe}, \mathrm{Cd}, \mathrm{pb}, \mathrm{Al}$ and other elementals such as $\mathrm{Zn}$ which have very low correlation.

Table 6. Correlation coefficients for elements in the bed sediment during the three seasons of 2012.

\begin{tabular}{|c|c|c|c|c|c|c|c|c|c|c|c|c|}
\hline & $\mathbf{C u}$ & $\mathbf{F e}$ & $\mathbf{C d}$ & $\mathbf{M g}$ & $\mathbf{Z n}$ & $\mathbf{P b}$ & $\mathbf{A l}$ & $\mathbf{B a}$ & $\mathbf{N i}$ & $\mathbf{M n}$ & $\mathbf{A g}$ & $\mathbf{C r}$ \\
\hline $\mathbf{C u}$ & 1.00 & & & & & & & & & & & \\
\hline $\mathbf{F e}$ & $\mathbf{0 . 6 6}$ & 1.00 & & & & & & & & & & \\
\hline $\mathbf{C d}$ & $\mathbf{0 . 6 9}$ & $\mathbf{0 . 9 3}$ & 1.00 & & & & & & & & & \\
\hline $\mathbf{M g}$ & 0.39 & $\mathbf{0 . 7 6}$ & 0.57 & 1.00 & & & & & & & & \\
\hline $\mathbf{Z n}$ & -0.28 & -0.53 & -0.64 & -0.63 & 1.00 & & & & & & & \\
\hline $\mathbf{P b}$ & 0.28 & $\mathbf{0 . 8 4}$ & $\mathbf{0 . 6 4}$ & $\mathbf{0 . 7 8}$ & -0.31 & 1.00 & & & & & & \\
\hline $\mathbf{A l}$ & 0.03 & $\mathbf{0 . 7 1}$ & 0.54 & $\mathbf{0 . 7 9}$ & -0.47 & $\mathbf{0 . 9 4}$ & 1.00 & & & & & \\
\hline $\mathbf{B a}$ & -0.12 & $\mathbf{0 . 6 5}$ & 0.47 & $\mathbf{0 . 6 5}$ & -0.29 & $\mathbf{0 . 8 9}$ & -0.94 & 1.00 & & & & \\
\hline $\mathbf{N i}$ & -0.17 & $\mathbf{0 . 6 2}$ & 0.54 & 0.62 & -0.56 & $\mathbf{0 . 7 7}$ & $\mathbf{0 . 9 0}$ & $\mathbf{0 . 9 3}$ & 1.00 & & & \\
\hline $\mathbf{M n}$ & $-\mathbf{0 . 1 7}$ & 0.53 & 0.27 & $\mathbf{0 . 7 5}$ & -0.26 & $\mathbf{0 . 8 0}$ & $\mathbf{0 . 8 7}$ & $\mathbf{0 . 9 2}$ & $\mathbf{0 . 8 2}$ & 1.00 & & \\
\hline $\mathbf{A g}$ & -0.09 & -0.20 & -0.19 & -0.41 & $\mathbf{0 . 5 2}$ & -0.35 & -0.49 & -0.18 & -0.28 & -0.12 & 0.00 & \\
\hline $\mathbf{C r}$ & 0.04 & $\mathbf{0 . 7 2}$ & $\mathbf{0 . 6 7}$ & $\mathbf{0 . 7 3}$ & -0.73 & $\mathbf{0 . 7 9}$ & $\mathbf{0 . 9 2}$ & $\mathbf{0 . 8 6}$ & $\mathbf{0 . 9 6}$ & $\mathbf{0 . 7 4}$ & -0.47 & 1.00 \\
\hline
\end{tabular}

High correlation coefficient between $\mathrm{Cd}$ and $\mathrm{Fe}(\mathrm{r}=0.93)$; $\mathrm{Cd}$ and $\mathrm{Cu}(\mathrm{r}=0.69)$; $\mathrm{Al}$ and $\mathrm{Fe}(\mathrm{r}=0.71) ; \mathrm{Cr}$ and $\mathrm{Fe}(r=0.72)$ and $\mathrm{Fe}$ and $\mathrm{Mg}(\mathrm{r}=0.76)$ oxides can play a role in the retention of trace metals and this explained by their origin from the same source (i.e. industry, urban origin and transport). Thus, Cd, Fe, Mg and $\mathrm{Cu}$ appear to be associated with to discharges from urban origin, which typically contains large amounts of organic matter.

The given elements, such as $\mathrm{Cr}, \mathrm{Cd}$ and $\mathrm{Ni}$ have interacted with organic matter in the aqueous phase and settled resulting in a high concentration of these elements in the sediment [26, 27].

Negative correlation means that the metals do not have common sources and this might be due to the variation in the sources.

\section{Factors analysis}

The factors analysis is a tool for the recognition of variables structures and for differentiation evaluation of pollution in the sediments. Principal component analysis for the sediments of LLRB is shown in Table 7. It includes loading for the rotated component matrix, eigenvalues for each component, per cent and cumulative per cent of variance explained by each component. It indicates that the three principal components together account for $90.56 \%$ of the total variance in the data set, in which the first principal component is $62.96 \%$, second principal component is equal to $17.43 \%$, and the third principal component is $10.17 \%$. The first factor is positive loaded by $\mathrm{Zn}, \mathrm{Ba}, \mathrm{Ag}$ and negatively loaded by $\mathrm{Fe}, \mathrm{Cd}, \mathrm{Mg}, \mathrm{Pb}$, $\mathrm{Al}, \mathrm{Ni}, \mathrm{Mn}$ and $\mathrm{Cr}$.

$\mathrm{Ni}$ and $\mathrm{Cr}$ are probably associated with industrial effluents (e.g. chromium-plating). While Cd behaves different source than the other two groups. This metal appears in the most mobilisable fractions in many sampling points and a variety of pollution sources may contribute to the Cd existence in the sediments.

The results shown in the Figure 3 reveal that the classification of class (i.e. season) is not important and this appears in the Figure 2. For examples, the class $1 \backslash 3$ contains S1 MRS, S1 DS, and not all the selected sites of winter sampling. This classes $1 \backslash 3$ was found in positive side of the axis of $\mathrm{F} 1$ and has the same character. 
Table 7. Factor loadings of elements data in the sediments samples

\begin{tabular}{|c|c|c|c|}
\hline Variables & F1 & F2 & F3 \\
\hline $\mathrm{Cu}$ & -0.24 & $\mathbf{0 . 9 2}$ & $\mathbf{0 . 2 3}$ \\
\hline $\mathrm{Fe}$ & -0.86 & $\mathbf{0 . 4 3}$ & -0.27 \\
\hline $\mathrm{Cd}$ & -0.73 & $\mathbf{0 . 5 8}$ & -0.14 \\
\hline $\mathrm{Mg}$ & -0.86 & 0.15 & 0.03 \\
\hline $\mathrm{Zn}$ & $\mathbf{0 . 6 3}$ & -0.34 & -0.54 \\
\hline $\mathrm{Pb}$ & -0.92 & -0.04 & -0.23 \\
\hline $\mathrm{Al}$ & -0.96 & $\mathbf{0 . 2 3}$ & 0.04 \\
\hline $\mathrm{Ba}$ & $\mathbf{0 . 8 9}$ & -0.40 & -0.21 \\
\hline $\mathrm{Ni}$ & -0.89 & $-\mathbf{0 . 3 4}$ & 0.05 \\
\hline $\mathrm{Mn}$ & -0.81 & -0.47 & -0.21 \\
\hline $\mathrm{Ag}$ & $\mathbf{0 . 4 2}$ & -0.11 & -0.77 \\
\hline $\mathrm{Cr}$ & -0.95 & -0.11 & $\mathbf{0 . 2 0}$ \\
\hline Eigenvalues & $\mathbf{7 . 5 5}$ & $\mathbf{2 . 0 9}$ & $\mathbf{1 . 2 2}$ \\
\hline \%Variance & $\mathbf{6 2 . 9 6}$ & $\mathbf{1 7 . 4 3}$ & $\mathbf{1 0 . 1 7}$ \\
\hline \% cumulative & $\mathbf{6 2 . 9 6}$ & $\mathbf{8 0 . 3 9}$ & $\mathbf{9 0 . 5 6}$ \\
\hline
\end{tabular}

Figure 4 shows that the distribution in the first class is characterized by the presence of $\mathrm{Ag}$ and $\mathrm{Zn}$ and the second class is characterized by the presence of $\mathrm{Cd}, \mathrm{Cu}, \mathrm{Fe}$ and $\mathrm{Mg}$ due to many industries and the reject of waste water without recycling.

In the third class, it was found in the positive site of F2 and negative site of the axis of F1 and which are characterize by the presence of $\mathrm{Pb}, \mathrm{Mn}, \mathrm{Mg}$ and $\mathrm{Ba}$.

Sites S1and S2 are characterized by the presence of Zn and Ag, then the sites S3, S4 and S5 are characterized by the presence of $\mathrm{Cu}, \mathrm{Cd} \mathrm{Mg}$ and Fe. Whichmean that they has the main source of pollution,S6 is characterize by the presence of $\mathrm{Pb}, \mathrm{Cr}, \mathrm{Al}, \mathrm{Ni}$, Ba and $\mathrm{Mn}$.

The nutritional requirements of elements ( $\mathrm{Cu}, \mathrm{Zn}$ etc.) differ substantially between species or elements, and optimum ranges of concentrations are generally narrow,-Given elements ( $\mathrm{Pb}, \mathrm{Cd}$ etc.) exhibit extreme toxicity even at trace levels [28], which are the characteristics of the sediment in the study area.

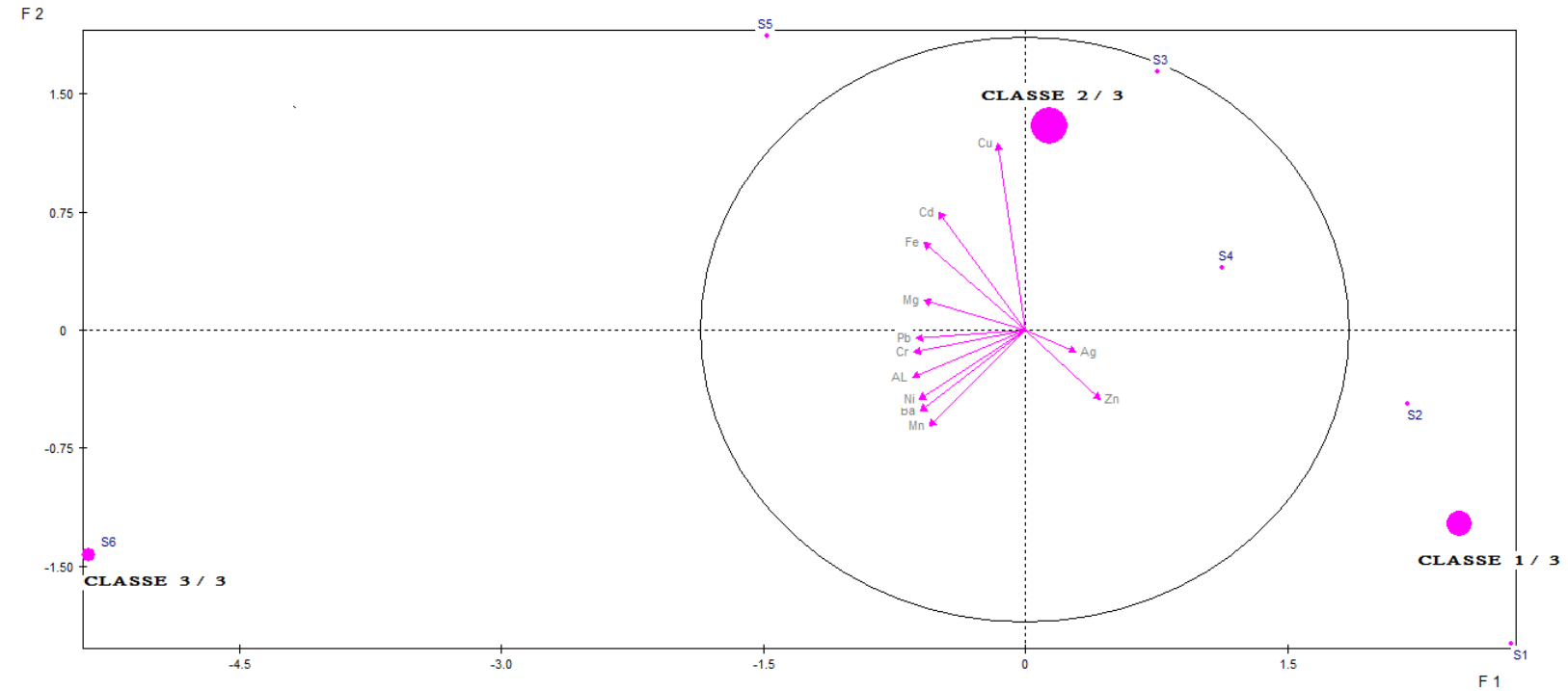

Fig. 3: Factorial F1and F2 classification by the mean. 


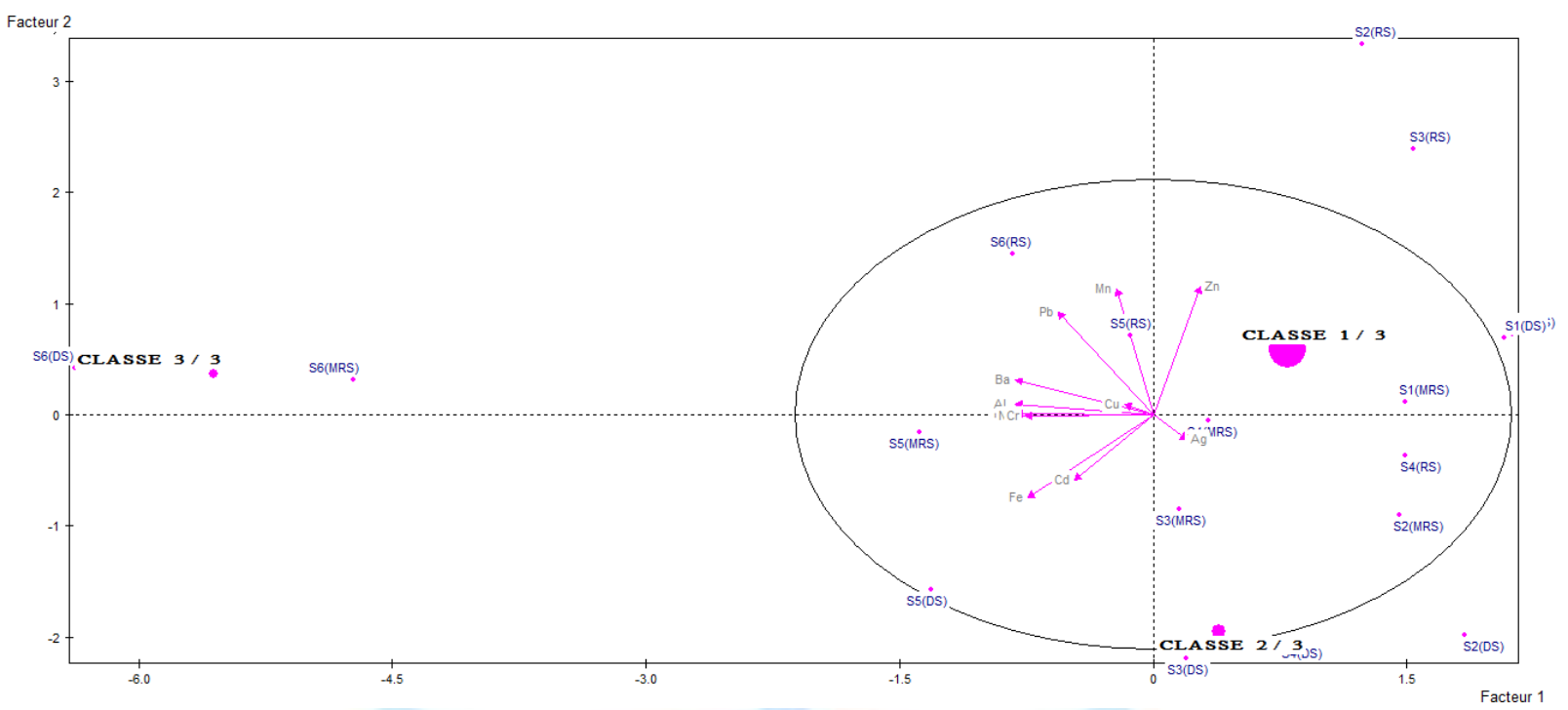

Fig. 4: Factorial F1 and F2 classification by the seasons.

\section{CONCLUSION}

The results of water analysis of the LLRB showed that the heavy metals concentrations were mainly within the permissible limits according to the norms introduced by WHO and Libnor. However, significant local water pollution problems were found (in S1), which are due to the increasing swept-out effluents along different drains into the river and extensive water use, and thus the quality of river water is exposed to deterioration. In recent years, the impact of the wastes (i.e. solid and liquid) discharged on ambient water of the LLRB has been significant due to the high self-assimilation capacity of the river water.

The heavy metal concentrations in the river sediments were remarkably high, but varied among sampling sites. The results suggest that special attention must be given to the issue of element re-mobilization, because a large portion of elements in sediments are likely to release back into the water column. Special attention should be paid to mitigate pollution from these sources as their effects may become significant during seasons and years of low water flow in the river. Therefore, periodical monitoring on the LLRB river water quality is needed to record any alteration in the quality and mitigate outbreak of health disorders and the detrimental impacts on the aquatic ecosystem.

However, partitioning patterns highlighted with exception of $\mathrm{Zn}, \mathrm{Ag}$ (site 1 and Site 2) and $\mathrm{Cr}, \mathrm{Pb}, \mathrm{Al}, \mathrm{Ni}$ and $\mathrm{Mn}(\mathrm{Site} 6)$, Cu, $\mathrm{Cd}, \mathrm{Fe}$ and $\mathrm{Mg}$ (Site 5) metals were mainly associated with the residual fraction and hence, the possibility to affect the water quality is minimal. Whilst, Cd displayed the highest mobility and bioavailability, since it was largely distributed among the non-residual phases and Cd will be mobilized from sediment to water [29].

$\mathrm{Cu}$ is high on the (Site 5) the latter may confirm the anthropogenic origin of $\mathrm{Cu}$ at that point, probably as a consequence of sewage effluents (i.e. both domestics and industrials).

$\mathrm{Ni}$ and $\mathrm{Cr}$ association and its negative correlation with $\mathrm{Cu}$ suggest a different source. An anthropogenic origin from urban effluents may be thought in case of $\mathrm{Cu}$.

Principal component analysis applied to total and extractable metal contents as a tool for studying heavy metal pollution of the LLRB, proved useful to distinguish between anthropogenic and geologic sources.By comparing the accumulation of heavy metals in water and sediments, it can be concluded that the heavy metals are highly accumulated in sediments of the LLRB than in water, since the sediments act as reservoir for all contaminants and dead organic matter descending from the ecosystem above, the total amounts of heavy metals in the six sampling sites distributed along the sediment of the LLRB course, indicate high pollution by heavy metals, according to the (CBSQG,ISQG) norms.

\section{REFERENCES}

[1] Caccia V. G, Millero F. J, Palanques A (2003) the distribution of trace metals in Florida Bay sediments. Marine Pollution Bulletin, Vol. 46, pp. 1420-1433.

[2] Jurdi M, Korfali SI, Karahagopian Y, Davies BE ( 2002) Evaluation of water quality of the Qaraaoun Reservoir, Lebanon. Suitability for multipurpose usage, Environ. Moni. Assess. 77, P11-30.

[3] Rammal., H.( 2007) A technical Report on the Post-Conflict impact on agriculture of coastal zone of the Litani basin.

[4] Khoury R, Doummar J, Khawlie M, Doumit A, Chaaban A, Abdalah C (2006), Using the Water Resources Model (WRM) for Optimization: the Lebanon Lower Litani River Case Study, WatMed3, Tripoli, Liban, November, pp. 6. 
[5] Nehme N, Haidar C, Koubaissy B, Fakih M, Awad S, Yaacoub A, Toufaily J, Hamieh T, Villeras F, Using Physicochemical and Microbial Parameters To Define the Quality of the Lower Litani River Bassin (LBL), CMS8, Unisco, Beirut 2012.

[6] Adeyemo, O. K, Adedokun, O. A, Yusuf, R. K, Adeleye, E. A (2008) Seasonal changes in physicao-chemical parameters and nutrient load of river sediment in Ibadan city, Nigeria. Global NEST Journal 10(3): P326 - 336.

[7] Kabata-Pendias A, Pendias H (1992) Trace Elements in Soils And plants, second ed. Florida CRC Press, Boca Raton.

[8] Biney C., Amuzu A.T., Calamari D., Kaba N., Mbome I.L., Naeve H., Ochumba P.B.O., Osibanjo O., Radegonde V. and Saad M.A.H., (1994) Review of pollution in the African aquatic environment, FAO, Rome.

[9] Zarazua G, Ávila-Pérez P., Tejeda S, Barcelo-Quintal I. and Martínez T\, (2006)Analysis of total and dissolved heavy metals in surface water of a Mexican polluted river by Total Reflection X-ray Fluorescence Spectrometry, Spectrochimica Acta Part B: Atomic Spectroscopy,(61), P1180-1184.

[10] APHA(1992) American public health association "APHA" Standard methods for the examination of water and wastewater. Washington, D.C. USA, 18th edn. 536 pp.

[11] Littlejohn, R. P. and J. L. McWhirter (1999). Using the EM algorithm to fit the Diggle-Zeger model for hormone profiles. 5th Australasian Genstat Conference, Lorne, Victoria.

[12] APHA(1995) American public health association "APHA" Standard methods for the examination of water and wastewater. Washington, D.C. USA, 19th edn. 698 pp.

[13] World Health Organization (WHO) (2006) A Proposal for Updating Lebanese Norm of Drinking Water (1999) based on WHO Guidelines. Lebanese Norm for Drinking Water(1999) , n 161, ICS 13.060.20.

[14] Elewa, A.A, Goher M.E.M. (1999) Environmental factors affecting the precipitation and dissolution of Fe, Mn, Zn, Cu, $\mathrm{Pb}$ and $\mathrm{Cd}$ in River Nile at Damietta branch. Bull. Fac. Sci., Zagazig Univ. 21(2): P114-136.

[15] Emerson R, Lewis C.M. (1939) Factors influencing the efficiency of photosynthesis, Amer. J. Boto. 26: P808-822.

[16] El-Sayed, M.A, El-Sayed M.Kh(1980) Levels of heavy metals in the surface water of a semi-enclosed basin along the Egyptian Mediterranean coast. Vas Hournees Etud. Pollution Commission Internaional pour l'Exploration Scientifique de la Mer. Mediterranée (C.I.E.S.M.), Monaco, 225-233 pp.

[17] Mucha, A.P, Vasconcelos, M.T.S.D,Bordalo, A.A (2003) Macro benthic community in the Douro Estuary: relations with heavy metals and natural sediment characteristics. Environmental Pollution 121: P169-180.

[18] Heiny J.S. ,Tate C.M. (1997) Concentrations, distributions and comparison of selected trace elements in bed sediment and fish tissue in the South, Platte, River, Basin, USA, 1992-1993. Archives of Environmental Contamination and Toxicology 32: P246-259.

[19] Warren, L.A, Zimmerman, A.P (1994) The influence of temperature and $\mathrm{NaCl}$ on Cadmium, Copper and Zinc partitioning among suspended particulate and dissolved phases in an Urban River. Water Resources 28: P19211931

[20] Nowack B, Kari F.G. , Kruger H.G.(2001) The remobilization of metals from iron oxides and sediments by metalEDTA complex. Water Resources 30: P1922-1935.

[21] Fabbri P, Gabbianelli G, Locatelli C, Lubrano P, Tormbini, C., Vassura I ( 2001) Distribution of mercury and other heavy metals in core sediments of northern Adriatic Sea. Water, Air and Soil Pollution 129: P143-153.

[22] Bordes $\mathrm{P}$, Bourg $\mathrm{A}$ (2001) Effect of solid/liquid ratio on the remobilization of $\mathrm{Cu}, \mathrm{Pb}$ and $\mathrm{Zn}$ from polluted river sediment. Water, Air and Soil Pollution 128: P391-400.

[23] Wisconsing Department of Natural Resources. (2003). Cncensus based sediment quality guidelines. Recommendations for use and application. Department of interior, Washington D.C. 20240 p 17.

[24] Laxen, D.P.H (1985) Trace metal adsorption/co-precipitation of hydrous ferric oxide under realistic conditions. Water Resources 19: P1229-1236

[25] Abdo, M. H (2004) Environmental studies on the River Nile at Damietta branch region, Egypt. J. Egypt. Acad. Soc. Environ. Develop. 5 (2): P 85-104.

[26] Pardo, R., Barrado, E, Perez, L. \&Vega, M (1990( Wat Res, (1990) 24(3), 373-379.

[27] Facetti, J., Dekov, V.M. \& Grieken, R.V (1998) Science of the Total Environment 209: 79-86.

[28] Nicolau R., Galera - Cunha A. and Lucas Y., (2006), Transfer of nutrients and labile metals from the continent to the sea by a small Mediterranean river, Chemosphere, 63, 469-476

[29] Goher, M.A. (1998) Factors affecting the precipitation and dissolution of some chemical elements in River Nile at Damietta branch. M.Sc. Thesis fact. of Sci. Menofia Univ. Egypt, 189 p 
First corresponding Author biography, Prof. Joumana Toufaily

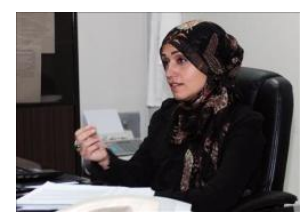

Dr. Joumana Toufaily, (born 1974), full professor at Lebanese University since 2007 in the field of Inorganic and Physical Chemistry of Materials. She is Adjunt Professor and Fulbrighter at the School of Mechanical and Materials Engineering Washington State University, She was honored by The Department of State of USA in Science Hall of Fame in 2013, as one between 12 outstanding female scientists throughout the Middle East and North Africa. She is Coordinator of the Master 2 Research: Physical Chemistry, Materials and Catalysis and Coordinator of the Laboratory of Materials, Catalysis, Environment and Analytical Methods (MCEMA), Lebanese University, Lebanon. Education: She has obtained her PhD in Physico-Chemical domain in 2002 in UHA. After this, she was Post-doc at the Laboratory of Catalysis in Organic Chemistry (LACCO), ESIP, Poitiers, France. Research field: Hybrid Organic-Inorganic Materials, NanoscienceNanotechnology, Sol-gel Chemistry, Self-assembly, Nanostructuration, In-situ and post-synthesis functionalization, Heterogeneous catalysis, Environment. She is Director of $2 \mathrm{PhD}$ students, Co-Director of $10 \mathrm{PhD}$ students and Director of 24 master's degree thesis. References: She is co-author of 30 publications in international scientific journals and 37 communications in the area of elaboration, characterisation and application of of solid organic-inorganic hybrid materials.

\section{Second corresponding Author biography, Director of the MCEMA Laboratory}
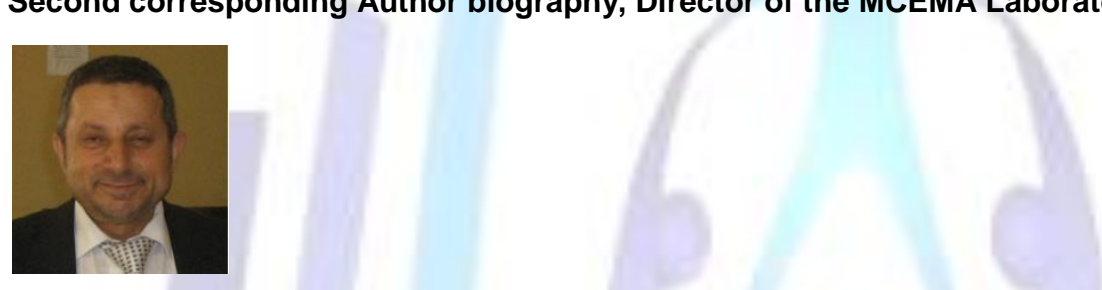

Prof. Tayssir HAMIEH (born 1955), He was the Dean of the Faculty of Agriculture (Lebanese University, from 2008 to 2014), full Professor at the Lebanese University since 1996, He was Professor at the University of Haute-Alsace (Mulhouse - France) until 2000, Visiting professor (1998) in University of Alberta, Canada. He obtained his first PhD in Physical Chemistry (1985), his HDR (1996) and obtained in 2001 his second Ph.D. in Mathematics from UHA. He published more than 250 Papers in Specialized Journals and international conferences. Prof. Hamieh also served on many academic and administrative responsibilities and Coordinator and Editor of huit international conferences on Materials Sciences (CSM) held in Beirut in 1996, 2000, 2002, 2004, 2006, 2008, 2010 and 2012; Editor of Journal of Physique IV, Volume 124, EDP Sciences, France, 2005; and Editor of Physics Procedia (CSM7). 